\title{
Star Patterns on the Circassian Mamluk Plated Doors
}

\section{Star Patterns on the Circassian Mamluk Plated Doors}

Composite geometric motifs ${ }^{(1)}$ occurred aside to the simple one in the Circassian doors; star patterns a term which is mentioned by the composite forms. Of early types of stars components occurred also in a carved wood panel from Takrit dated to $2^{\text {nd }}$ $\mathrm{AH} /$ send half of $8^{\text {th }} \mathrm{AD}$ century ${ }^{(2)}$. From the early Islamic Times, interlaced geometric ornaments occurred as first occurrence of Composite ornaments. The remarkably intact mosque of Ahmad Ibn Tulūn, shows particularly in the decoration of suffits of the arches adjoining the southwest corner of the Sahn, that geometric art of specifically Islamic types was present in Egypt in the $3^{\text {rd }} \mathrm{AH} / 9^{\text {th }} \mathrm{AD}$ century ${ }^{(3)}$. Prototypes occurred like the famous 8-pointed star and cross pattern occurred in Qasr al-Hayr al-Garbī which confirms the idea of the earliest ornaments of Sammarä ${ }^{-{ }^{(4)}}$.

\section{Star pattern's first occurrence}

Due to estimations given by Farīd $\check{S}^{a}{ }^{\prime}{ }^{‘} \overline{1}$, the first occurrence of the star pattern had given its first light in the beginning of the $6^{\text {th }} \mathrm{AH} / 12^{\text {th }} \mathrm{AD}$ century ${ }^{(5)}$. That was in a portable mihrab ${ }^{(6)}$ for Sayyidah Ruqaīyah (Fig.1) "slave of the Fatimid caliph al-Amir bi Ahkām Allah" dated to 549-555AH/1154-1160AD, which forms hexagons kindāt, enclosed six-pointed stars however, this is not a complete star pattern, but as estimated by Farīd Sāfi'īa a stage of variety of geometric patterns, the artisan wasn't reformed to a complete star pattern ${ }^{(7)}$ The spaces between the star patterns were filled with geometric inlays like stars and pentagons ${ }^{(8)}$ while the inner cavity of the mihrab is engraved with composite geometric elements based six-pointed stars surrounded by six pentagons, lack in almonds lawzāt to be complete star patterns ${ }^{(9)}$ The units of the star pattern are gradually developed in the Ayyubīd period reached its complete form in a wood catafalque for Imām al-Šăfi ${ }^{\prime} \overline{1}$ in his mausoleum dated to $574 \mathrm{AH} / 1178 \mathrm{AD}$. The central tirs has six lobes surrounded by six hexagonal patterns musadasāt followed by twelve

(1) A term of which could be nominated to multi-groups of geometric patterns by its presence in one single unit. Each individual unit has its own artistic meaning and terminology. In this point I would rather mention the types of composite elements summarized in the star patterns. For more details on the forms of composite elements see Hankin. E.H, A drawing of Geometric Pattern in Saracenic Art, India, 1925. Fig.36; 'Isam.al-Sayid, Issa.Perman, Geometric Concept in Islamic Art, London, 1976, Figs.35b,35c, 35d, 36a, b, c; Lee. A.J, Islamic Star Patterns, Muqarnas, Leiden, 1987, IV, figs. 17, 18, 20,22 .

(2) Dimand. M.S, Studies in Islamic Ornaments, ArsIsl, Michigan I, Fig. 4.

(3) Creswell.K.A.C, Early Moslem.Architecture, Oxford, 1932, Vol II, p. 346.

(4) Huda al-Batanouni, Catalogue of Mamluk Doors With Metal Revetment, M.A, AUC, Cairo, 1975, p. 153.

(5) Farīd Sāfi ‘̄i, al-'Imārah al-'arabiyah fí 'Asr al-Wullah, Cairo, 2002, p. 219.

(6) A portable wood mihrab made of Turkish wood. See Cairo, Museum of Islamic Art, Inv.No: 446.

(7) Farīd Šāfi'̄i, Mumayazāt al-ah̆šāb al-muzahrafah fi-l-tirāzayn al-'Abbāsi wa-l-Fatimì fi Miṣr, BFA, Bull. Of the Faculty of Arts, Cairo University, Vol.XVI, Part I, May, 1954, p.84; Abd al-Ra'üf. A. Yūsuf, al-Hă̌ab wa-l-'āğ, Kitab al-Qāhirah, Tarihuhāa, Ațāriha wa funūnhā, Cairo, 1969, p.360; Ahmad 'Abd al-Rāziq, al-Funūn al-islāmiyah hatā nihayat al-'asr al-fātimī, Cairo, 2006 p.97.

(8) Kühnel. Ernst, Mamlukische Kassettenstil, Kunst des Orients KunstOr, Wiesbaden, I, Abb. 1.

(9) F.Šafi ‘̄i, Mumayzāt al-Ahšāb, BFA, XVI, Pt. 1, p. 84. 


\section{Star Patterns on the Circassian Mamluk Plated Doors}

almonds lawzāt and then twelve irregular hexagons kindat $t^{(1)}$ resembling those found in the mihrab in the citadel of Nūr al-Dīn at Damascus ${ }^{(2)}$

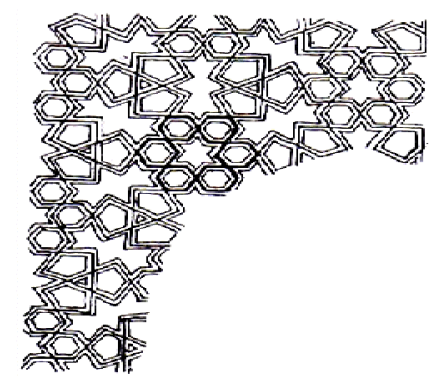

Fig. 1

Star patterns in the mihrab of Sayyidah Ruqaīyah After. Kühnel, Mamlukische Kassettenstil, KunstOr, I

The star pattern reached its peak in the mamluk period, the central star or tirs was once having 16 lobes instead of six occurred in most of the mamluk artifacts specially the $\operatorname{wood}^{(3)}$. For the mamluk doors, the earliest type of doors that mainly applied with star pattern revetment is the door of the mosque of Baybars I "now adorns the entrance of the French embassy ${ }^{(4)}$, another one introduced to his mosque built at al-Husayniyah; parts of it were preserved in the Victoria and Albert Museum of art ${ }^{(5)}$. By looking to these two doors, rapid development occurred. For the first time we could see 7-poined star pattern in the door of the madrasah of Baybars adjoining 12-pointed star pattern in the central part ${ }^{(6)}$. Due to this rapid development of the star patterns occurred in the mamluk doors, they became one of the main characteristic features of the overall cast revetment doors, beginning from the Bahrite period which witnessed remarkable innovations of doors with star patterns ${ }^{(7)}$.

(1) Kühnel, Mamlukische Kassettenstil, KunstOr, I, Abb.5; Baer, Ornament, Fig. 103

(2) Herzfeld. Ernst, Damascus: Studies in Architecture, ArsIsl, X, p.75, Fig.81.

(3) Aḥmad 'Abd al-Rāziq, al-Funūn al-islāmīyah,fi-l-'aṣrayin al-Ayyūbī wa-l-mamlīkì, Cairo, 2007, p.83

(4) Creswell. K.A.C, Moslem Architecture of Egypt, Oxford, 1959, Volume,II ,p.146; A. 'Abd al-Rāziq, al-Funun, Ayyūbī wa mamlūkì p. 161.

(5) Briggs. Martin. S, Muhammadan Architecture in Egypt and Palestine, Oxford, 1924, p.223. Fig. 232.

(6) Bourgoin. Jules, Précis de 1'art arabe, La Menuiserie, Paris, 1892, Pl. 42

(7) Țaha 'Imārah, al-Abwāb al-musạafahah fi 'ahd al-sultān Hasan bi-l-Qāhirah, Thesis submitted to the faculty of Archaeology, Cairo University, 1984, I, p. 211. 


\section{Star Patterns on the Circassian Mamluk Plated Doors}

Standard evolution occurred in the doors of the Circassian period; however, the star pattern could be developed to have 20 - pointed character like that occurred in the door main door of the madrasah of Ibn Muzhir ${ }^{(1)}$. The main door of Barqūq's madrasah is considered the final innovation of the Bahrite mamuk system of overall star pattern doors. The bronze door is a simpler version of sultan's Hasan's prototype preserved now in the mosque of al-Mu'ayyad ${ }^{(2)}$. The door distribution of the star patterns could be be analyzed as 10-pointed star patterns scattered in between 18-pointed ones seems to have been developed between simple geometric elements as parts from star patterns ${ }^{(3)} \mathrm{A}$ A complete 10-pointed star as first could be seen (Fig.2) (Pl.I) with all its artistic components. The central boss (Fig.2/a) is however, shown in the centre of the star while it is inlaid with silver and decorated with interlaced geometric components forming rose like motif. The protruding boss is fixed with nails over 10-pointed star tirs followed by 10 almonds lawzāt (Fig. 2/b) then 10 hexagons kindāt (Fig.2/c) attached to craw's nests bayt $\dot{g} u r a \bar{b}$ (Fig. 2/d) and five-pointed stars.

The radiating distribution of this star unit is simply presented while the hexagons and almonds were entirely incrusted with silver inlay forming lotus flowers and stylized foliate branches. The central boss of this door occurred before in the main door of the madrasah of sultan Hasan in the mosque of al-Mu'ayyad within 12, and 16-pointed star patterns. ${ }^{(4)}$

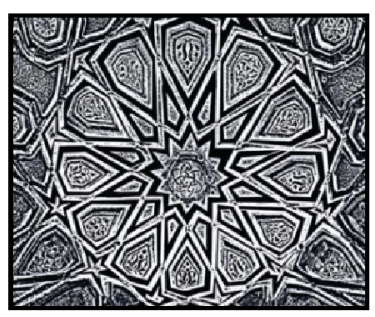

Fig. 2

10-pointed star pattern Barqūq -main door

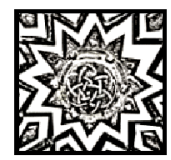

Fig. 2/a

Tirs-boss

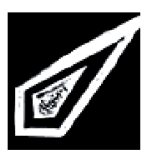

Fig. $2 / \mathrm{b}$

lawzah

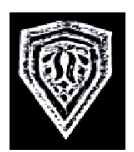

Fig.2/c

kindah

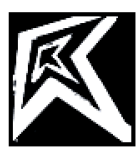

Fig. $2 / \mathrm{d}$

bayt $\dot{g} u r a \bar{b}$

Done by the researcher

In the same door, 18-pointed star patterns occurred (Fig.3). (Pl.II) The symmetrical composition of the star pattern begins with the center of the metal faced front. The star system begins with central star boss (Fig.3/a) (P1.III) tirs covered by a boss perfectly inlaid with silver bears the name of sultan Barqūq. The central star is followed by

(1) H.al-Batanouni, Mamluk Doors, p. 124, Fig. 16; Mols. Luitguard, Mamluk Metalwork Fittings in their Artistic and Architectural Context, Netherlands, Eburon, 2006, p. 289. Pls. 191-194.

(2) Martin.H, L'art musulman, Paris, 1926, p.14 ; Hasan 'Abd al-Wahāb, Tārīhn al-Masāğid al-atariyah, Cairo, 1948, Volume I, p.194 ; Stierlin. Henri, Splendors of an Islamic World, U.K, 1997, p. 118; Doris Abu Seif, Cairo of the Mamluks, London 2007, p. 228.

(3) Prisse d'Avennes, L'art arabe d'apres le monuments du Kaire, Atlas, Paris, 2001, p.115, Pl.XCVII

(4) Martin, L'art, Pl.III; Hautecoeur. Louis et Wiet. Gaston, Les mosquées du Caire, Paris, 1932, Volume Volume II, Pl.129 


\section{Star Patterns on the Circassian Mamluk Plated Doors}

almonds lawzat (Fig.3/b) which are simply attached to a group of hexagons kindāt (Fig.3/c) and finally bayt al-gurāb (Fig.3/d) in the edge of the unit close to five-pointed stars. . The representation of the star pattern is a simpler version of the star unit occurred in the main door of the mosque of al-Mu'ayyad belongs to sultan Hasan ${ }^{(1)}$ especially in the representation of the central boss and the arrangement of the geometric units.

In the door of the madrasah of al-Kurdī, 12-star pattern occurred in the center point of the buharriyah. It is shown in its complete form (Fig.4/a). The star pattern here is quite simple with its components; central star tirs, almonds lawzāt, hexagons kindāt. Its position in the central part of the medallion could give it a repetition in the inner frames of the theme (Fig.4) (P1.IV) in which -half 12-star patterns are shownThe spaces between them are filled with 5-pointed stars (Fig.4/b) scattered everywhere. This standard evolution of the star patterns of twelve points could rather be seen in the doors from the Bahrite period like the main door of the mosque of al-Mu'ayyad belongs to sultan Hasan $^{(2)}$ especially in the representation of the central boss and the arrangement of the geometric units.

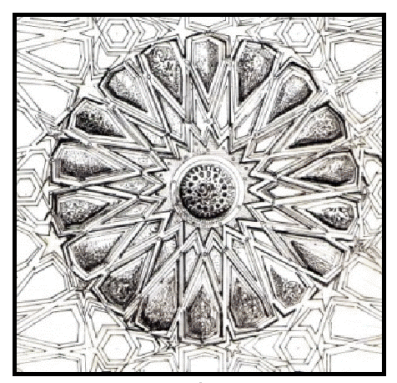

Fig. 3

18-pointed star pattern- Barqūq main door

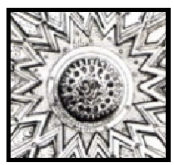

Fig. 3/a

Tirs-boss

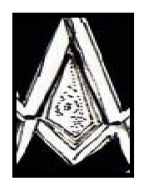

Fig. $3 / \mathrm{b}$

lawzah

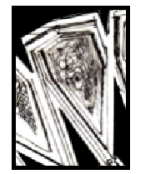

Fig. 3/c kindah

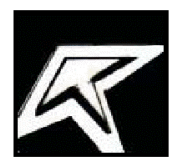

Fig. 3/d

bayt gurāb

Done by the Researcher
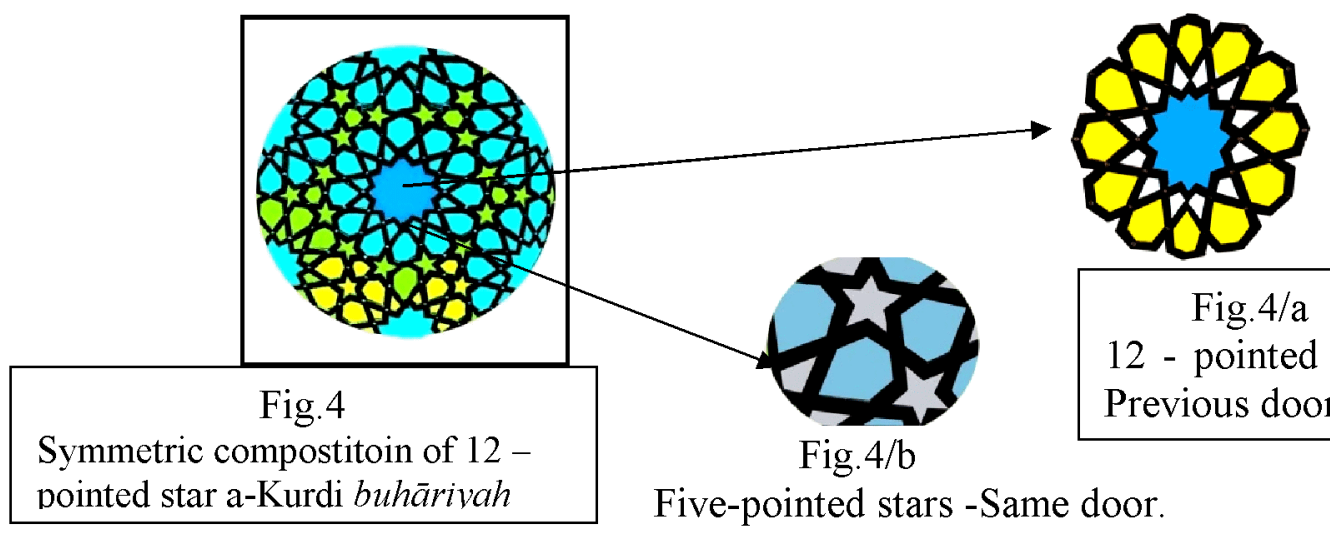

Fig. $4 / \mathrm{a}$

12 - pointed star

Previous door

Fig. $4 / \mathrm{b}$

Five-pointed stars -Same door.

Done by the researcher

(1) Martin, L'Art, P1. III; T. 'Imārah, $a l-A b w a \bar{b} b$ I, Fig. 1, and, II, P1. 20.

(2) Martin, L'Art, P1. III; T. 'Imārah, al-Abwāa I, Fig. 1, and, II, P1. 20. 


\section{Star Patterns on the Circassian Mamluk Plated Doors}

In the door of the madrasah of al-Kurdī, 12-star pattern occurred in the center point of the buharriyah. It is shown in its complete form (Fig.4/a). The star pattern here is quite simple with its components; central star tirs, almonds lawzāt, hexagons kindāt. Its position in the central part of the medallion could give it a repetition in the inner frames of the theme (Fig.4) (P1.IV) in which -half 12-star patterns are shown. The spaces between them are filled with 5-pointed stars (Fig.4/b) scattered everywhere. This standard evolution of the star patterns of twelve points could rather be seen in the doors from the Bahrite period like the main door of the mosque of al-Mu'ayyad belongs to sultan Hasan ${ }^{(1)}$ the main door in the madrasah of Baybars I preserved in the French embassy $^{(2)}$ and the main door of his mosque preserved in the Victoria and Albert Museum $^{(3)}$.

The same stars occurred in the quarter rounds of the same door (Fig.5). It could be identified as half 8-pointed star patterns. The previous half star pattern is enclosed within five-pointed stars and crow's nests biy $\bar{u} t \dot{g} u r a \bar{b}$. The whole system is quite different to that of the buhāriyah, and it is not necessarily be a rule to find them similar, but the nature of the quarter round must be similar to that of the buhāriyah especially in the type " $\mathrm{B},{ }^{(4)}$ and " $\mathrm{C}$ " of the Circassian doors

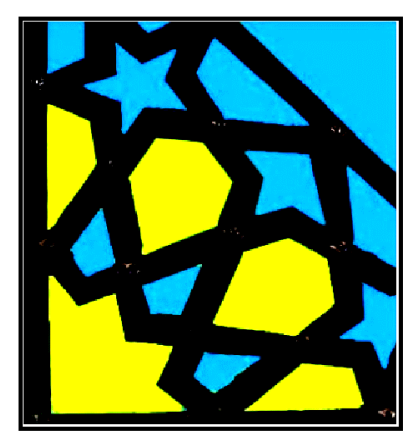

Fig.5

Half -8-pointed star patterns-quarter round

Previous door- done by the researcher

The 11-pointed star patterns occurred in the main door of the madrasah of 'Abd alGanī al-Fahrî ${ }^{-5)}$. (Fig.6) (Pl.V). The unit acquired a unique criteria ${ }^{(6)}$ ever occurred in the

(1) Martin, L'Art, PI.III ;T. 'Imārah, al-Abwāa, II, Pl. 28

(2) Bourgoin, Précis de l'art, Pl. 42

(3) Briggs. Muhammadan Architecture. Fig.232.

(4) A Type of doors combined between the overall star patterns door "Type A" and the open work

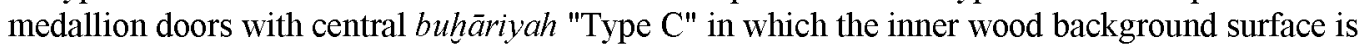
covered with a thin layer of brass with open work decoration.

(5) Muhammad al-Kaḥlāwī, Munša'at al-amīr 'Abd al-Gañ̄ al-Fahrī (Ğāmi ' al-banāt) bī šāri' Bur Sa 'id , M.A, Thesis, Faculty of Archaeology, Cairo University, 1981, pp. 31, 32; Molls, Metalwork Fittings, p. 259

(6) Its really a unique criteria because its very rare to find this type of star patterns occurred in the mamluk art, however, the Bahrite mamluk doors have varied types of star patterns between 8 to 16 pointed stars (see T.'Imārah, $a l-A b w a \bar{a} b, \mathrm{pp} .207-222$ ), while in the Circassian plated doors, the stars reached 20 pointed taking a special criteria 


\section{Star Patterns on the Circassian Mamluk Plated Doors}

mamluk star patterns considering as a transitional step between the occurrence of the 6 and 20 pointed star patterns occurred in the Circassian plated doors and became to be an evolution of the star patterns in the Circassian plated doors. In this star, the radiating decorative units emerged from the central star tirs (Fig.6/a) (Pl.VI) followed by almonds lawzāt (Fig.6/b) then hexagons kindāt (Fig.6/c). The open work technique is shown within the units giving vegetal character based on stylized undulating foliate patterns. The whole system is bordered by a group of crow's nests bayt al-giurāas as usual in the star patterns.

In the same door 10-pointed stars occurred. They are technically applied in open work emphasizing the idea of the vegetal character within the interior units. The stars occurred and are centered by a boss (Fig.7) (Pl.VII) which is filled with raised open work vegetal units based on stylized foliate branches terminated with split-leaves technically applied and centered by a protruding oval medallion. The bosses occurred in such a Bahrite doors like that of the main door of sultan Hasan in the mosque of alMu'ayyd Šayh. The main door of sultan Hasan in the mosque of al-Mu'ayyad has mainly 16-pointed star pattern with central boss in the middle ${ }^{(1)}$. The same character occurred in 12-pointed star in the main door of the Hānqāh of Baybars al-Ğăšinkīr ${ }^{(2)}$. Central bosses occurred in the stars of the main door of Barqū ${ }^{(3)}$.

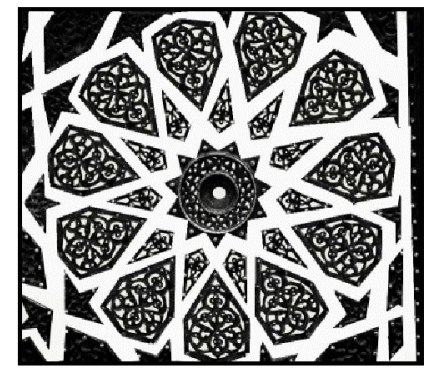

Fig.6

11-pointed star pattern- al-Fahriyah - main door

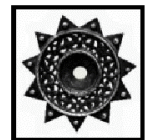

Fig. 6/a Tirs

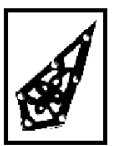

Fig. 6/b

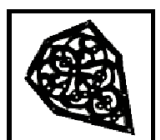

Fig. 6/c almond-lawzah hexagon kinda

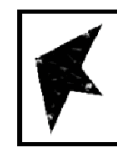

Fig. 6/d bayt $\dot{g} u r \bar{a} b$

Done by the Researcher

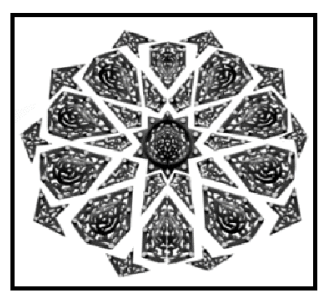

Fig. 7

10-sided star - al-Fahriyah - main door

(1) Wiet, Mosquées, II, P1.129;Martin, L'Art, P1.III; T. 'Imārah, al-Abwāa I, Fig. 1, and, II, P1. 20.

(2) Wiet, Mosquées, II, P1.99; H.al-Batanoun̄̄, Mamluk Doors, P1.VII/b

(3) Prisse d'Avennes, L'Art, Pl.XCVII. 


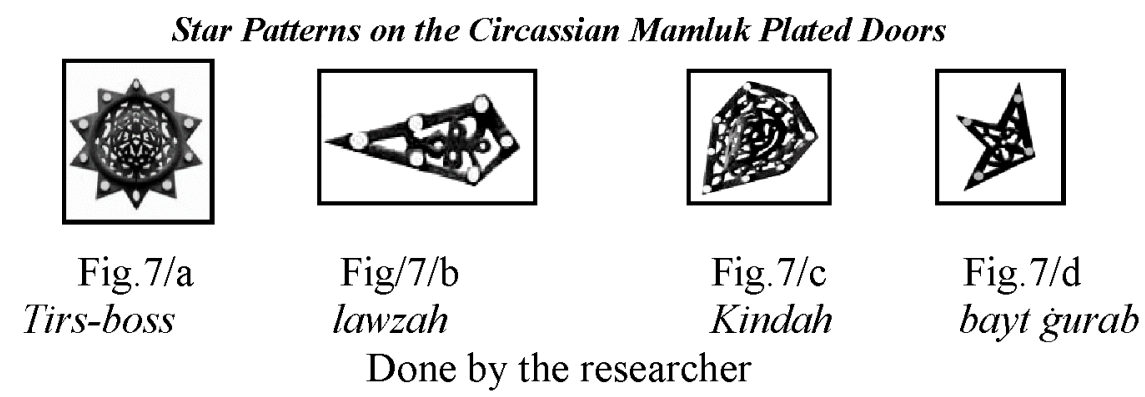

The central bosses became popular criteria in the Circassian doors as a way of its evolution. The same technique occurred in the 10-pointed star occurred in the main door of the madrasah of Abū Bakr ibn Muzhir (Fig.8) (Pl.VIII) . Protruding areas are noticed in the stars attachments almost seen in the central boss, hexagons kindāt. The 10pointed star patterns ${ }^{(1)}$ are scattered chiefly around big star units and within pentagonal stars, and anșāf zuqāq. They are running in oval movement and centered by a $20-$ pointed star pattern. The same attachments are seen; tirs (Fig.8/a) almonds lawzōt (Fig.8/c) hexagons kindät (Fig. 8/c). The star pattern reached high grades of evolution in the same door; 20-pointed star pattern is shown in the central part of the metal faced front (Fig.9) (Pl.IX). The interior units applied in open work technique filled with open work foliate units based on stylized stems terminated with split-leaves and calices. By the way, this prototype is considering the marvelous of all in my point of view because of its professionally applied open work and never repeated in any door of the Circassian period.

The previous star example has also its own attachments, clearly shown like tirs, almonds lawzāt, hexagons kindāt, all applied in open work with interior foliate motifs based on stylized leaves and branches. Palmettes and split-palmettes occurred within the decoration program of the attached elements of the star pattern.

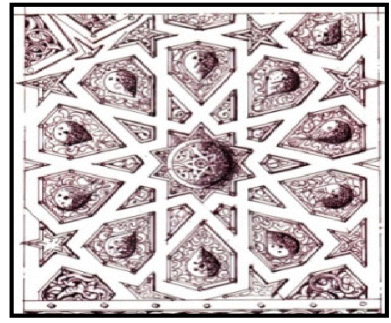

Fig. 8

10-pointed star pattern - Ibn Muzhir door- Done by the researcher

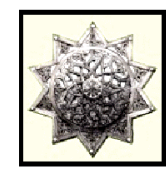

Fig. $8 / \mathrm{a}$

Star - boss

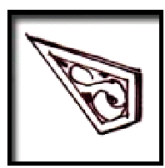

Fig. $8 / \mathrm{b}$

almond lawzah

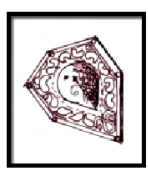

Fig. $8 / \mathrm{c}$ hexagon kindah

(1) Comité de conservation des monuments de la art arab, Le Caire, Exercice, 1897, Deux cent vingtquatrième rapport. - Examen, Des rabais faits sur les travaux du budget de 1896, Pl.IV; 'Āṣim Rizq, Mağmu'at ibn Muzhir, Cairo, 1995, p.79; Mols, Metalwork Fittings, pp.288-290. 


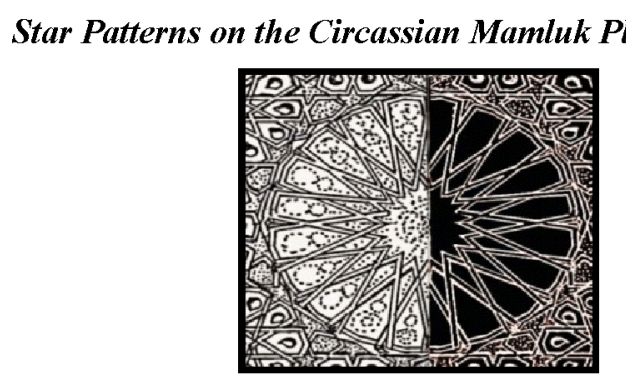

Fig. 9

20-pointed star pattern- ibn Muzhir door

Done by the researcher

Star patterns occurred in the door of the madrasah of Qiğmās al-Ishāqī. 12-pointed star pattern found in the central buhāriyah of the metal faced front (Fig. 10) (Pl.X). The same location of the star pattern occurred in the central buhäriyah of the door of the madrasah of Mahmūd al-Kurdī (Fig.4). 12-pointed star patterns occurred in some doors from the Bahrite period; for example: the main door of the madrasah of Baybars I preserved in the French embassy ${ }^{(1)}$ the main door of the mosque of Baybars I preserved in the Victoria and Albert Museum ${ }^{(2)}$ the central overall cast front of the main door of the madrasah of mosque of Ulmās al-Hāğib ${ }^{(3)}$ the main door of sultan Hasan in the mosque of al-Mu'ayyad ${ }^{(4)}$ the right tomb door of the same madrasah ${ }^{(5)} \mathrm{T}$.' Imārah, al$A b w \bar{a} b$, II, Pl.142 and half 12-pointed star in the door of the minbar of the same $\operatorname{madrasah}^{(6)}$.

In the door of the Hānqāh-dome of al-Gawrī, Five complete 12-pointed star patterns occurred in the two leafs of the door. The star units are incised with foliate decorative designs based on stylized branches terminated by leaves (Fig.11) (PI.XI). The central star tirs has incised decorative cross like shape stayed within a plenty of foliate stems. The cross sign here is not identified as a blazon, it is just only an ornamentation. The 12-pointed stars are setting in a dense of geometric attachments; pentagonal stars and hexagons are clearly shown.

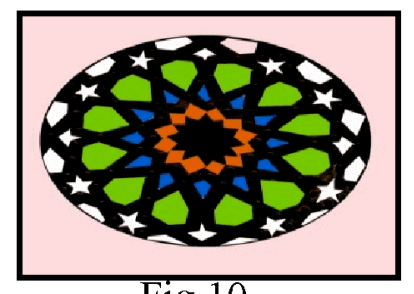

Fig. 10

12-pointed star-buhāriyah

- Madrasah of Qiğmās

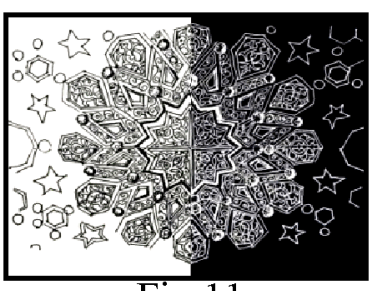

Fig. 11

12-pointed star - buhāriyah

Hānqāh- Dome of al-Gawrī

Done by the researcher

(1) Bourgoin, Précis de l'art, Pl.42; .al-Batanouni, Mamluk doors, Pl.

(2) Briggs. Muhammadan Architecture. Fig. 232.

(3) Prisse d'Avennes, L'art arabe, II, Pl.C.

(4) Martin, L'art, P1.III; Hautecoeur et Wiet, Mosquées, II, Pl.129

(5) Herz, Mosquée du sultan Hasan, p.31; T.'Imārah, al-Abwāb, II, Pl.76

(6) T.'Imārah, al-Abwāb, II, Pl.142 


\section{Star Patterns on the Circassian Mamluk Plated Doors}

The door of the madrasah of the same patron has similar representation of the door with 12-pointed star pattern. The difference is in the central boss which covers a rounded shield of an epigraphic blazon bears the name and titles of sultan Qanșuwah alGawrī (Fig. 12) (Pl.XII). The foliate interior subjects of the geometric attachments are similar to that of the Hānqāh (Fig.11). The previous star pattern is located among a dense of geometric units; five-pointed stars, and hexagons are clearly shown.

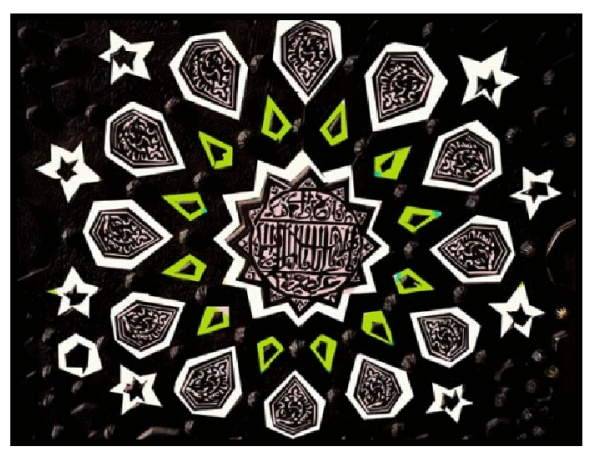

Fig. 12

12-pointed star pattern al-Gawrī - madrasah Main Door

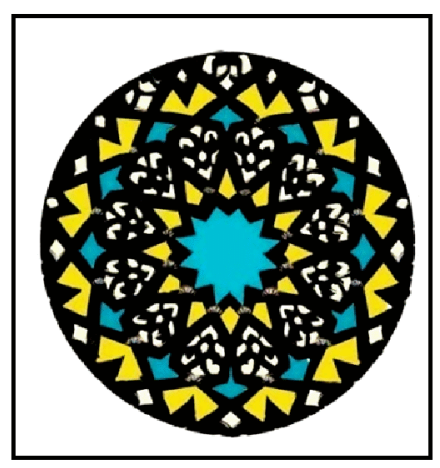

Fig. 13

12-pointed star pattern al-Gawrī madrasah Rear door-buhāriyah

Done by the Researcher

The design of the previous star resembled that of the door of the mosque of Ulmās ${ }^{(1)}$ while a row of five-pointed stars are running around the pattern. In the same madrasah, rear door located in the northeastern side of the building. A simple trilobed entrance is embarrassing an open work medallion door which covers both geometric and foliate motifs. Its central medallion has 12-sided star pattern in the central core of the buhāriyah (Fig.13) (P1.XIII). Its hexagons kindāt are distinguished by its foliate character while a reciprocal trefoil leaves are set inside. The central star tirs is void of subjects followed by plain lozenges lawzāt than hexagons bearing trefoils as mentioned before. The compound of the star is a prototype occurred in the doors from the same period; the door of al-Kurd̄̄, for example (Fig.4), and the door of Qiğmās (Fig.10).

\section{Decorations evolved in the star patterns}

The foliate motifs occurred in the units within the star patterns. They are involved in the units of the star patterns such as the hexagons and almonds. They are applied in open work tafrig technique. Flowers such as the rose lotus ${ }^{(2)}$ occurred in the hexagons kindāt of the 10-sided star of the main door of Barqūq (Fig. 14). Split-winged palmettes occurred in the hexagons kindāt of the 12-sided stars of the same door (Pl.II). Stylized foliate branches occurred in the units of the 11-sided star patterns (P1.V) which terminated by trefoil leaves. The same devices occurred in the central stars bosses and

(1) Prisse d'Avennes, L'art arabe, II, Pl.C ; H.al-Batanouni, Mamluk Doors, Pl.V/b

(2) A type of flowers occurred firstly from the ancient Egyptian art which was a symbol of creation. It occurred in the Ptolemaic Roman walls Sassanid examples could be noticed, and are represented like a deep rounded cup form. They are fragmented to attain new shapes and articulations. Then it took a special criteria in Islamic Art, it occurred in the Bahrite mamluk doors such as the door knocker of the door of the tomb of sultan Hasan. See Erman. Adolf, A Handbook of Egyptian Religion, London, 1907, p.26,Fig.33; Pope, Ackerman, Persian Ornament, A Survey of Persian Art, Oxford University Press, London, 1938, Vol. VI, Fig.900/c-g; T. 'Imarah, al-Abwāb, I, p.320. 


\section{Star Patterns on the Circassian Mamluk Plated Doors}

the hexagons kindāt of the 10-pointed stars of the same door (PI.VII). Complete and split-palmettes occurred in the hexagons kindāt and the central star of the 20-pointed star on the door of the madrasah of Ibn Muzhir (Pl.IX).

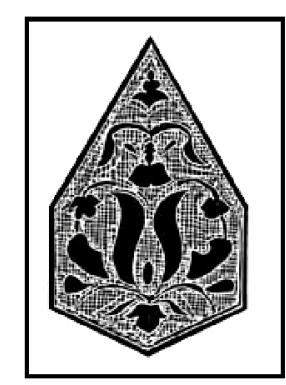

Fig. 14

Rose lotus in the 10-star of the Door of Barqūq

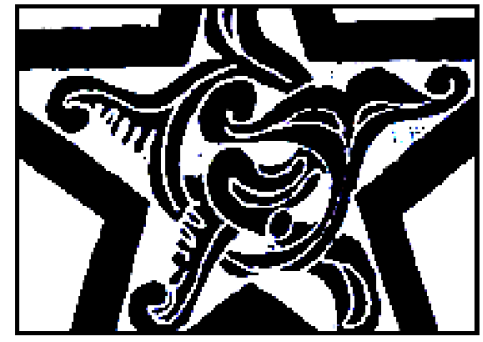

Fig. 15 spit-winged palmettes 5-pointed star- door of ibn Muzhir

Done by the researcher

Spilt winged palmettes occurred in the star patterns of the Circassian doors such as the five pointed stars in the door of ibn Muzhir (Fig.15). Calyx leaves are among the vital elements occurred in the Circassian star patterns of the doors. A device occurred in the central star of the 11-pointed star patterns in the door of 'Abd al-Ġani al-Fahri (Pl.VI). They are shown with three sepals and two bases spiral; a style occurred before in 'Irāq in a stone slab in the mausoleum of Imām Yahiya 637AH/1239AD ${ }^{(1)}$. Similar prototype occurred in the door from the madrasah of al-Ṣālih Nağm al-Dīn Ayyūb $640 \mathrm{AH} / 1242 \mathrm{AD}$ preserved in the museum of Islamic Art in Cairo ${ }^{(2)}$. Rosettes are shown in the heptagons of the star patterns of the main door of Barquq (Figs. 16

,17) in the area within the star patterns. This unit is more naturalistic and was seen before in the early conventionalized motifs of the Dome of the Rock on the bands decorating the spandrels and the walls supporting the $\operatorname{arches}^{(3)}$.

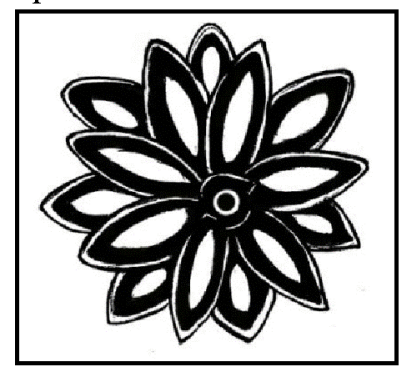

Fig. 16

Door of Barqūq

Heptagons

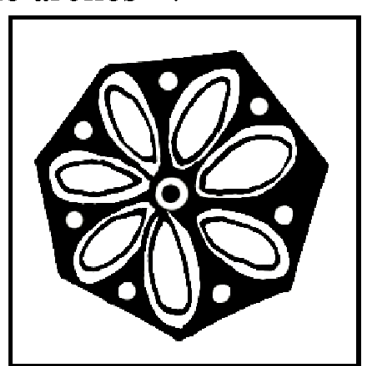

Fig. 17

Door of Barqūq

Heptagons

Done by the researcher

(1) Farīd Šăfi'î, Simple Calyx Ornaments in Islamic Art, A study in Arabesque, Cairo University Press, 1957, P1.32/c.

(2) F. Šafi'ī, Simple Calyx, P1.32/g

(3) Creswell. K.A.C, Early Muslim Architecture, Oxford, 1932, Pl. 32/g. 


\section{Star Patterns on the Circassian Mamluk Plated Doors}

Stylized foliate branches and stems enclosed by split-leaves occurred in the hexagons kindāt of the main door of the madrasah of 'Abd al-Ganī al-Fahrī (Fig. 18). The main system is a sole branch intertwined in a wavy position, terminated by trefoil palmettes and split-leaves intersected forming a nude. Stylized branches were seen in the central star of 20-pointed star of the main door in the madrasah of ibn Muzhir (Fig. 19) giving undulating scrolls of motifs which carry split-palmettes run in different directions.

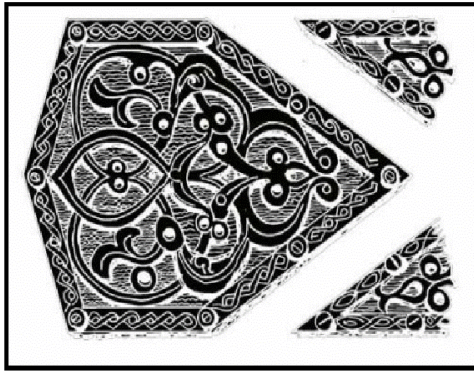

Fig. 18

Kindah- 11-pointed star door of al-Fahrī

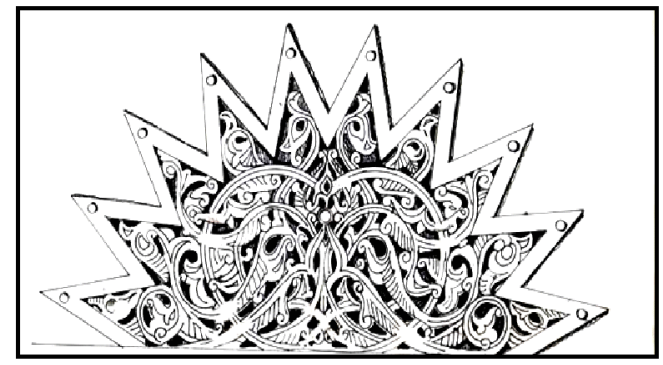

Fig. 19

20-pointed star- door of ibn Muzhir

Done by the researcher

Trefoil blossoms occurred in the same area from the door of 'Abd al-Ganī al-Fahrī (Pl.VI) and the hexagons kindāt of the 12-pointed star in the rear door of the madrasah of al-Gawrī (P1.XIII). Palmettes and split-winged palmettes occurred also in the hexagons of the 12-pointed star pattern in the main door of the madrasah of al-Gawri (Fig.20), whereas stylized foliate branches with stems occurred in the $z u q \bar{a} q$ in the area within 11-pointed star patterns in the door of al-Fahriyah (Fig.21). The same form of patterns occurred in the spaces separating between the 16, and the 12-pointed star patterns in the Sultan Hasan's main door in the mosque of al-Mu'ayyad ${ }^{(1)}$. Epigraphic motifs are among the focal elements occurred in the star patterns of the Circassian plated doors. Epigraphic motifs are among the focal elements occurred in the star patterns of the Circassian plated doors. Separate words had been carved on the bosses of the star patterns like the name of Barqūq which occurred in the central boss of the 12pointed stars in the main door of Barqūq (Fig.22) (P1.III).

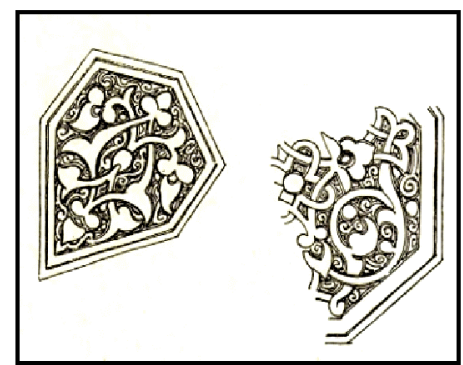

Fig. 20

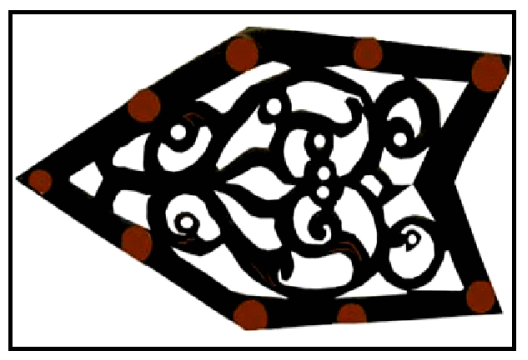

Fig. 21

$z u q \bar{a} q$ - area within 11-pointed star done by the researcher 


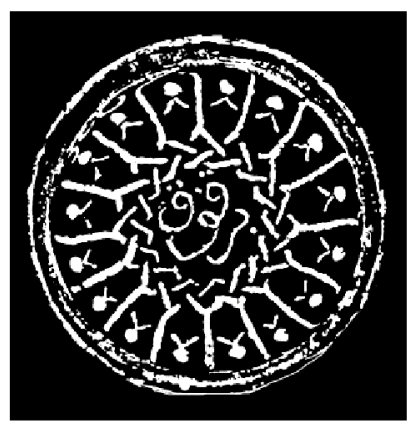

Fig. 22

Barqūq's main door Boss of 18 pointed star pattern

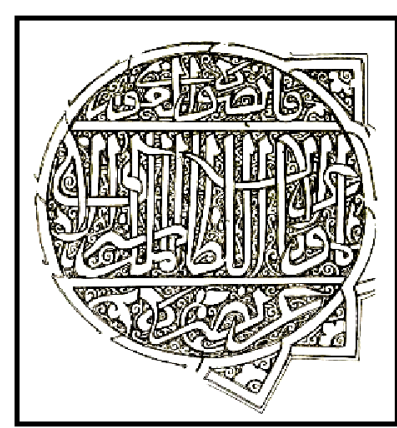

Fig. 23

al-Gawrī madrasah

Central star tirs - 12-pointed star pattern

Epigraphic shields also appeared clearly in the central stars of the Circassian doors. The central star of the 12-pointed star pattern of the door of the madrasah of al-Gawrī which carried the epithet of the sultan ${ }^{(1)}$ لمولانا السلطان الملك الأشرف- ابو النصر قانصوة Glory to our lord, the sultan, al-Malik, al-Ašraf Abu-1-Nașr Qanșūwah al-Gawrī, May his victory be glorified. The epithet is carved over a dense of foliate motifs (Fig.23) (Pl.XII). Other devices occurred in the central stars of the 12-pointed star patterns of the door of the Hānqāh-dome of the same patron. A central cross is shown in the middle of the star (Fig.11) (Pl.XI). It may represent the blazon of the cross, but in my opinion it is only just ornamentation. The ornaments within the units of the star patterns are almost applied by incising or even carving methods. Carving, engraving, and incising techniques were among the methods used in applying the decoration within star patterns shown obviously in the hexagons of the 12-pointed star in the door of al-Fahriyah (Fig.18), 20-pointed star pattern in the door of ibn Muzhir (Fig. 19). Carving and engraving were also applied in the hexagons of the 12-pointed star patterns in the door of the madrasah of al-Gawrī (Fig.20), and the hexagons of the irregular hexagons $z u q \bar{a} q$ in the area within the 11-pointed star patterns of the door of al-Fahriyah (Fig.21). The same techniques were used in applying the inscriptions inside the star patterns as seen in the epigraphic shields occurred in the central star of the 12pointed star pattern in the door of al-Gawrī (Fig.23). Other methods like inlaying takfit $^{(2)}$ applied in the central boss of the 18-pointed star pattern in the main door of the madrasah of Barqūq (Fig.22), and the 10-pointed star pattern in the door of the same patron.

(1) The same blazon occurred in many parts inside the madrasah of the sultan al-Gawrī with the same form and design scattered between several parts from the central courtyard and the Qibla wall. For more details see Muhammad Fahīm, Madrasat al-sulțān Qanșūwah al-Ğawrī, M.A. Faculty of Archaeology Cairo University, 1977, pp.69,171,172,190,192

(2) A Turkish word from Persian origin, several synonyms for term were used by the Arab artisan in different era like tarsī', talbiss, tarsīb, or tanzīl, while the most ancient term was tatbīq quite known in the Abbasid period. See Abd al-Nāsir.Yāsīn, al-Funun al-zuhrufiyay fi-l-'Asr al-ayyubī, Alexandria, 2002, p. 140; A.'Abd al-Rāziq, al-Funūn Ayyübi wa mamlūkī, p. 102. Quatrmére notified that the word kaft and plural kaftāt or akfät is putting precious material into another less precious substance while the term kafit points to the one who was inlaying the objects. See Quatrmére Hitoire des sultans mamluks de l'Egypte, Ecrite en arabe par Maqrīzī, traduit et accompagnée des notes phiolologique, hitsorique, géographique par Quatrmére, Paris, 1837, II/1, p. 114. 


\section{Star Patterns on the Circassian Mamluk Plated Doors}

Open work technique tafrig was also applied in the decoration of the star patterns as seen in the 12-pointed star pattern in the door of the madrasah of al-Kurdi (Fig.4) (Pl.IV), 12-pointed star pattern in the door of Qiğmās al-Ishāāi (Fig.10) (Pl.X), and the rear door of the madrasah of al-Gawrī (Fig. 13) (Pl.XIII).

\section{Summarized results}

As a result of this review on the geometric patterns, stars and geometric units of star patterns are considering major criteria of the simple motifs. Either five or six pointed stars were shown among the swimming star patterns of the rectangular fields from the doors.

From the most focal result revealed through this review that the doors from the type "B" and "C" have applied the star patterns for the first time in the mamluk art of metal work. They are shown in the door of al-Kurdī madrsah (Fig.4), and that of Qiğmās alIshāâ̄ (Fig. 10), and finally in the rear door of al-Gawrī madrasah (Fig.13). So we can firstly see a buhäriyah with star patterns. In those cases they are shown among a dense of open work cast revetment especially in the area within the star units.

It is rare to find the 11-pointed star patterns in the door of the madrasah of 'Abd alGani al-Fahrī (Fig.6) considering this step an evolution occurred in the star patterns of the both Bahrite and Circassian doors while it never occurs in other mamluk artifacts of metal or of any other material.

The study also revealed by examination of the star patterns; they are rapidly developed from 10 sided to be 20 -sided star patterns like that occurred in the main door of the madrasah of Ibn Muzhir (Fig.9) which has never been repeated anymore in the mamluk doors. Applying incised and inlaid foliate fillings of the star patterns units, considering a method occurred in the Bahrite mamluk doors then continued in the Circassian doors as well. This variation of the star patterns from 10 to 20 sided is considering a standard evolution extended from the Bahrite until the end of the Circassian period.

It is also rare to find the complete epigraphic blazons occurred in the mamluk doors as seen in the door of the madrasah of al-Gawrī (Fig. 14) (Pl.XII). A device has never been occurred in any of the Bahrite mamluk doors which reflects an evolution occurred in the Circassian star patterns.

Walīd Ahmmad Șalāḥ al-Dīn

Faculty of Arts

Ain Šams University 


\section{Star Patterns on the Circassian Mamluk Plated Doors}

\section{$\underline{\text { Related References }}$}

Arabic References:

'Abd al-Rāziq, Ahmad

al-Funūn al-islōmiyah hatā nihōyat al-'aṣr al-fātimì, Cairo, 2006. (al-Funūn hata nahāyat al-Fätimì)

al-Funūn al-islāmīyah,fi-l-'așrayin al- Ayyūbì wa-l-mamlūkī, Cairo, 2007. (al-Funūn, Ayyūbī wa mamlükī)

'Abd al-Wahāb. Hasan

Tārīhh al-Masāğid al-atariyah, Volume I, Cairo, 1948 (Masāăgid)

Fahīm Muhammad

Madrasat al-sulțān Qanșūwah al-Gawri, M.A, Faculty of Archaeology Cairo University, 1977. (Madrasat al-Gawri)

'Imārah Țaha 'Abd al-Qādir

al-Abwāb al-musafahah fi 'ahd al-sultān Hasan bi-l-Qāhirah, Thesis submitted to the faculty of Archaeology, Cairo University, 1984. (al-Abwäb)

al-Kaḥlāwī. Muḥammad

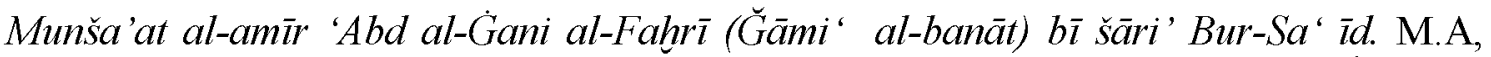
Thesis, Faculty of Archaeology, Cairo University, 1981. (Munš'at 'Abd al-Gani alFahrī)

Rizq. 'Āṣim

Mă̆mu'at ibn Muzhir, Cairo, 1995 (ibn Muzhir)

Šăfí'ī, Farīd

Mumayazāt al-ahšab al-muzahrafah fi-l-tirāzayn al-'Abbāsi wa-l-Fațimì fi Miṣr, BFA, Bull. Of the Faculty of Arts, Cairo University, Vol.XVI, Part I, May, 1954. (Mumayzāt al-ahšāa)

al-'Imārah al-'arabiyah fì 'Așr al-Wullāh, Cairo, 2002. (al-'Imarah)

Yāsīn. Abd al-Nāșir.

al-Fumūn al-zuhrufiyay fi-l-'Asr al-ayyūbī, Alexandria, 2002

Yūsuf, Abd al-Ra'ūf 'Alī

al-Hašab wa-l-'ā̆ğ, Kitāb al-Qāhirah, Tārihuhā, Ātârihā wa funūnhā, Cairo, 1969 (alHašab wa-l-'āğ)

\section{Foreign References:}

Abu Seif. Doris Behrins

Cairo of the Mamluks, London 2007 (Cairo)

al-Batanouni. Hoda

Catalogue of Mamluk Doors with Metal Revetments, M.A, AUC, Cairo, 1975 (Mamluk Doors) 
Bourgoin. Jules

Précis de l'art arabe, La Menuiserie, Paris, 1892 (Précis de l'art)

Briggs. Martin.S

Muhammadan Architecture in Egypt and Palestine, Oxford, 1924 (Muhammadan Architecture)

Comité de conservation des monuments de la art arab, Le Caire, Exercice, 1897, Deux cent vingt-quatrième rapport. - Examen, Des rabais faits sur les travaux du budget de 1896.

Creswell. Keppel Archbold Cameron

Early Muslim Architecture, Oxford, 1932 (E.M.A)

Moslem Architecture of Egypt, Oxford, 1959 (M.A.E)

Dimand Mourice.S

Studies in Islamic Ornaments, Some Aspects from Omaiyad and early Abbasid Ornament, Ars Islamica, Michigan, 1937 (Islamic Ornament)

Hankin. E.H

The Drawings of Geometric Patterns in Saracenic Art, Memoirs of the Archaeological Survey of India. No.15, India, 1925. (Geometric Patterns)

Hautecoeur. Louis et Wiet. Gaston

Les mosquées du Caire, Paris, Vol.I, 1932 (mosquées)

Herzfeld. Ernst

Damascus, Studies in Architecture-II, Ars Islamica, New York, 1968, Vol.X (Damascus)

Kuhnel. Ernst

Mamlukische Kassettenstil, KunstOr, Wiesbaden, I. (Mamlukische Kassettenstil)

Lee. A.J

Islamic Star Patterns, Muqarnas, IV, Leiden, 1987 (Star Patterns)

Martin. Henri

L'art musulman, Paris, 1926 (L'art)

Mols. Luitgard E.M

Mamluk Metalwork Fittings in their Artistic and Architectural Context, Netherlands, Eburon, 2006 (Metalwork Fittings)

\section{Prisse d'Avennes}

L'art arabe d'apres le monuments du Kaire, Atlas, Paris, 2001 (L'art arabe)

Quatremère, Étienne Marc 


\section{Star Patterns on the Circassian Mamluk Plated Doors}

Hitoire des sultans mamluks de l'Egypte, Ecrite en arabe par Maqrīzī, traduit et accompagnée des notes phiolologique, hitsorique, géographique par Quatrmére, Paris, 1837

al-Sayid .'Issām, Parman 'Issa

Geometric Concepts in Islamic Art, London, 1976 (Geometric Concepts)

Stierlin. Henri and Ann

Splendors of an Islamic World, U.K, 1997 (Splendors) 


\section{Plates}

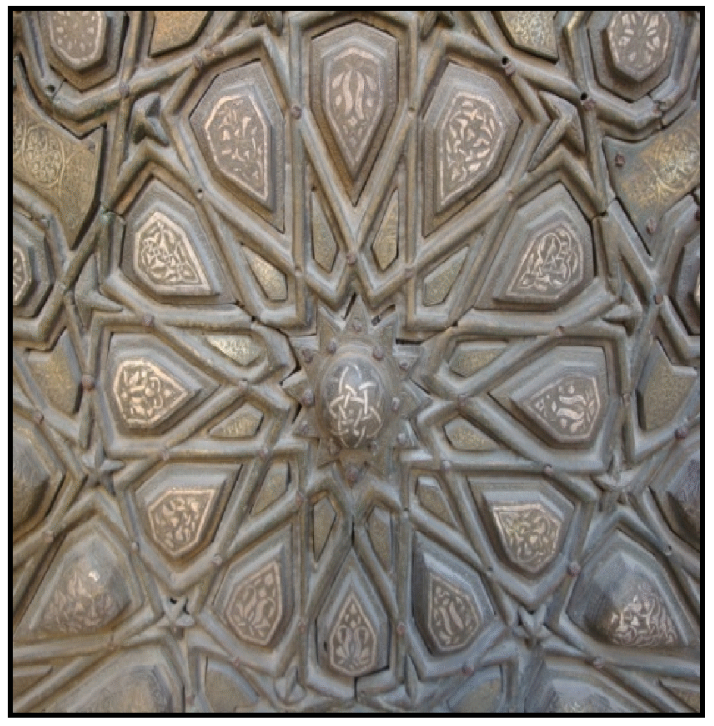

Plate. I

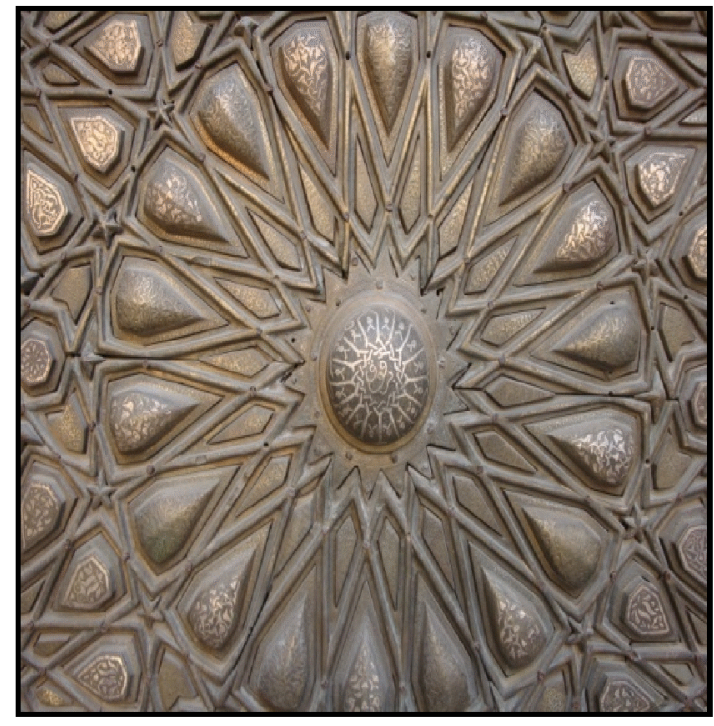

Plate II

10-pointed star pattern Barqūq -main door Photographed by the Researcher

18-pointed star- Barqūq-main door

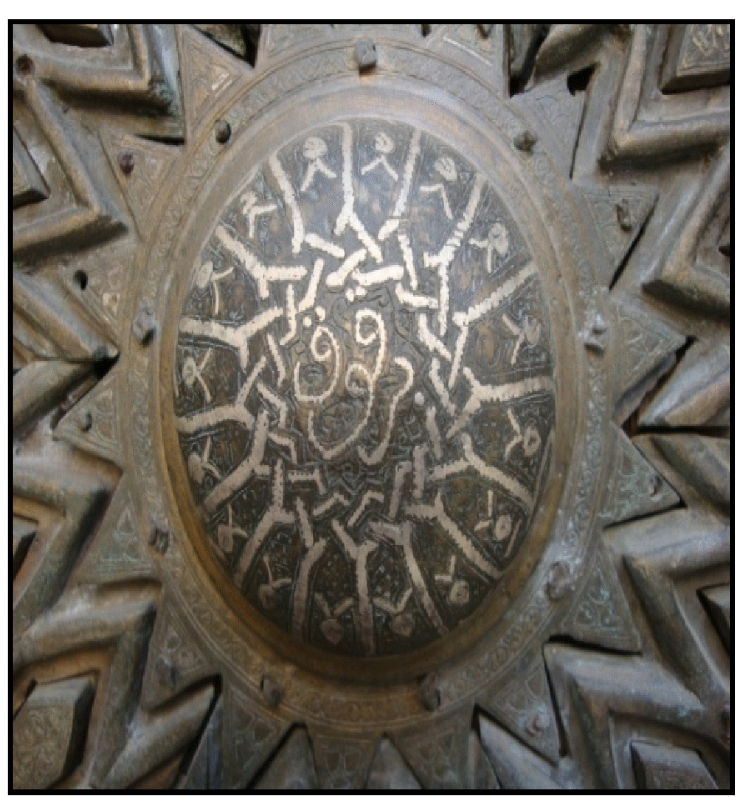

Plate III

Barqūq- Central boss-previous door Photographed by the researcher

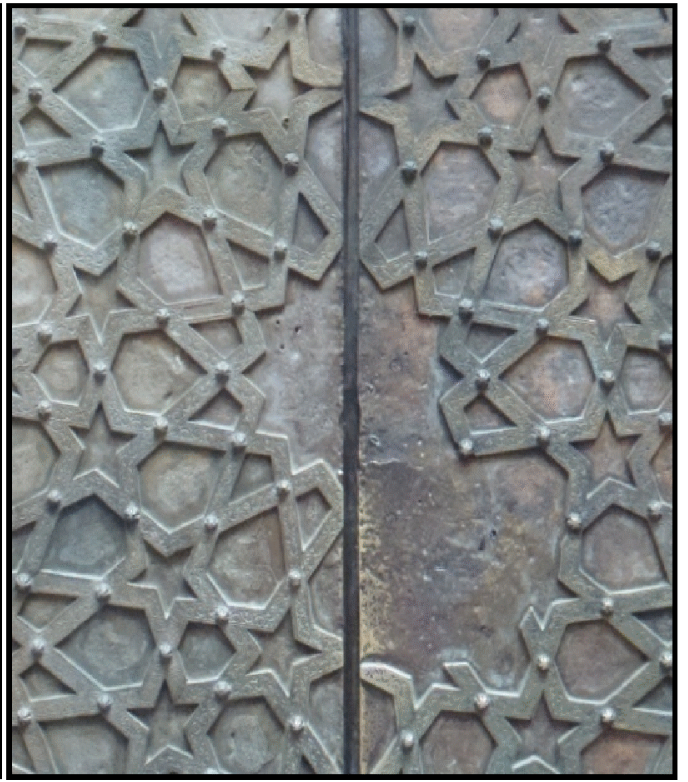

\section{Plate IV}

12-pointed star - door al-Kurdī madrasah 
Star Patterns on the Circassian Mamluk Plated Doors

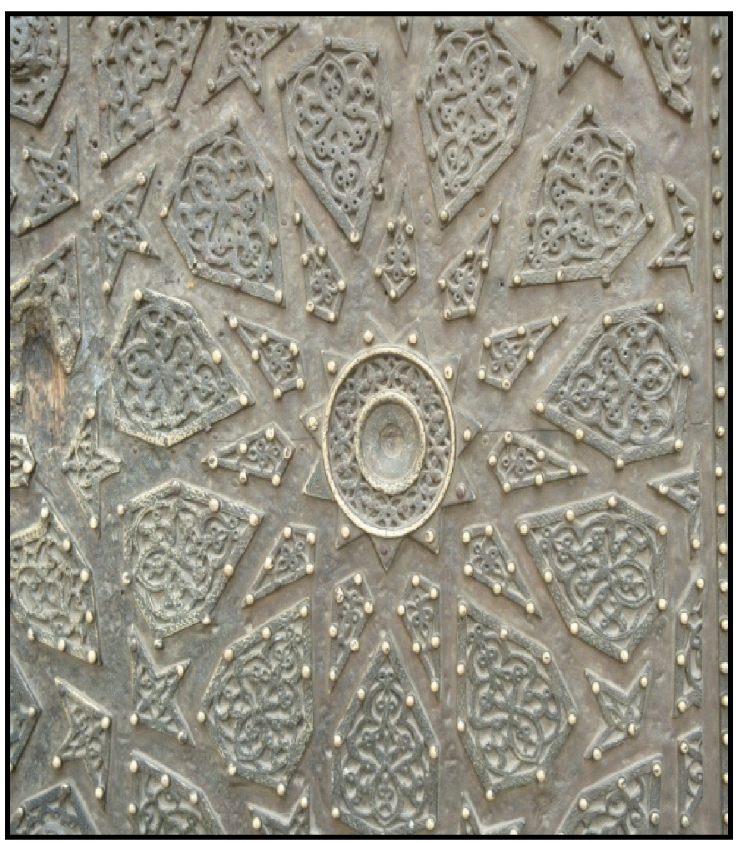

Fig. V

11-pointed star - door- al-Fahriyah madrasah Photographed by the researcher

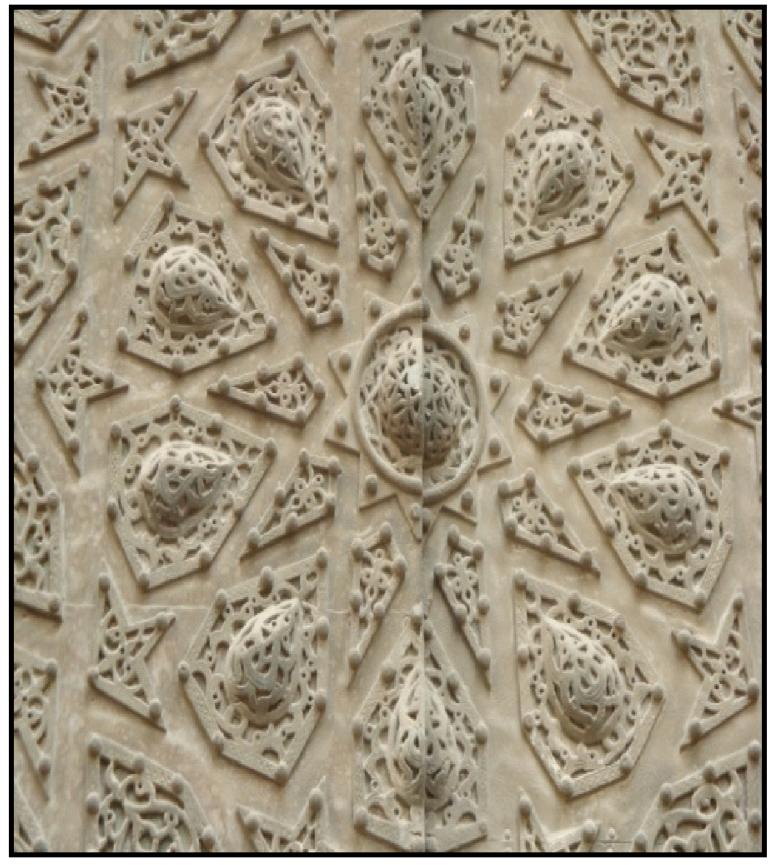

Fig.VII

10-pointed star pattern- previous door Photographed by the researcher

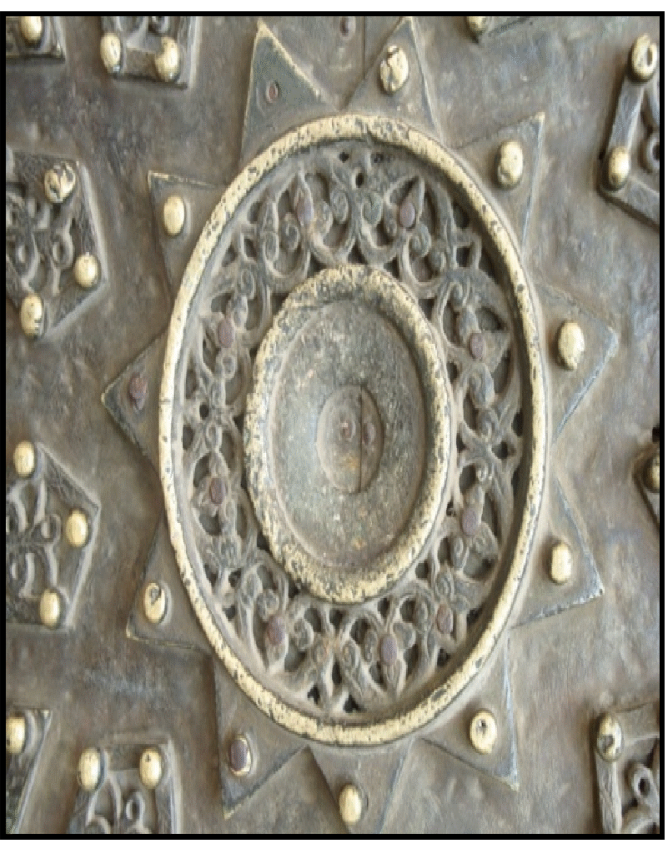

Fig. VI

central star-previous door

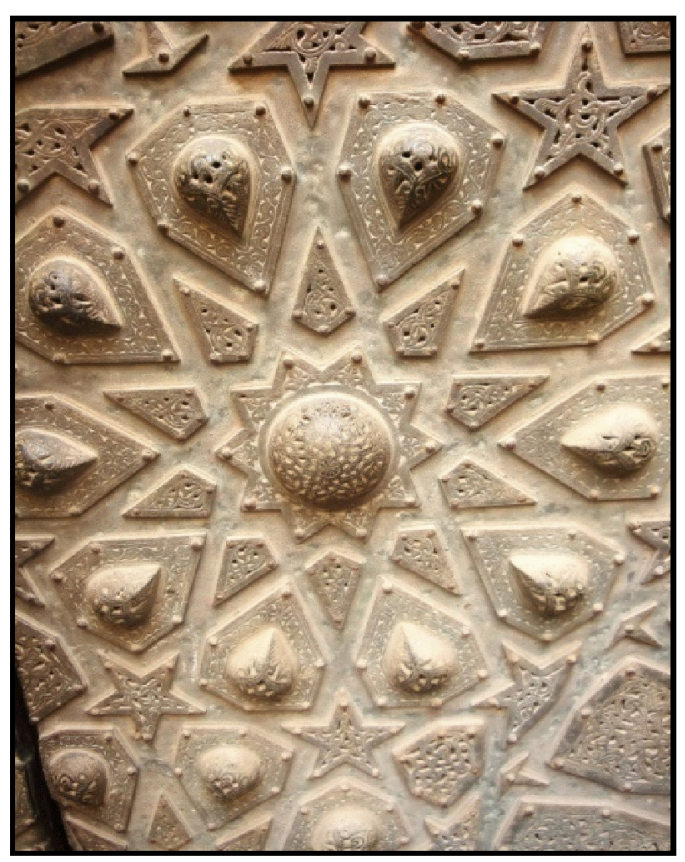

Fig. VIII

10-pointed star - Ibn Muzhir door 
Star Patterns on the Circassian Mamluk Plated Doors

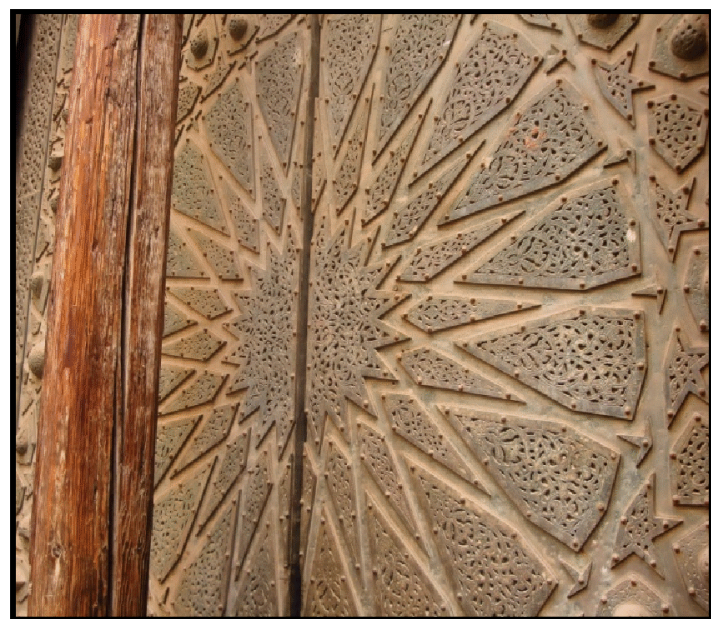

Plate.IX

20-pointed star pattern- Ibn Muzhir door

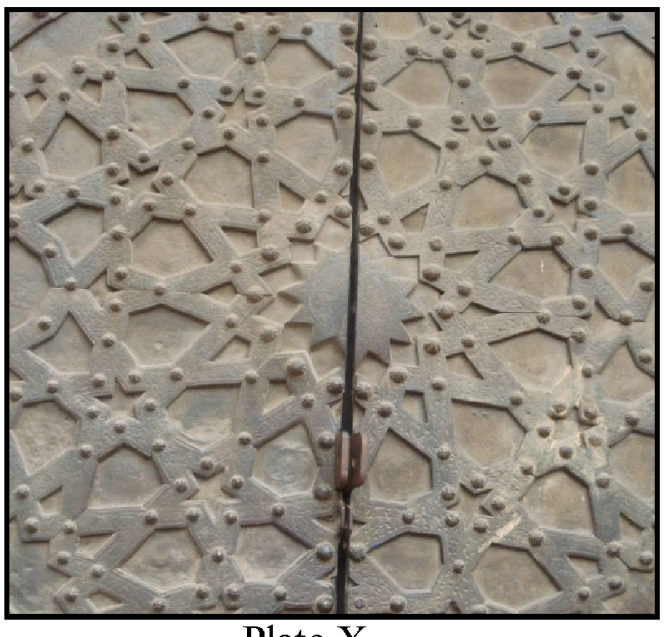

Plate. X

Photographed by the researcher

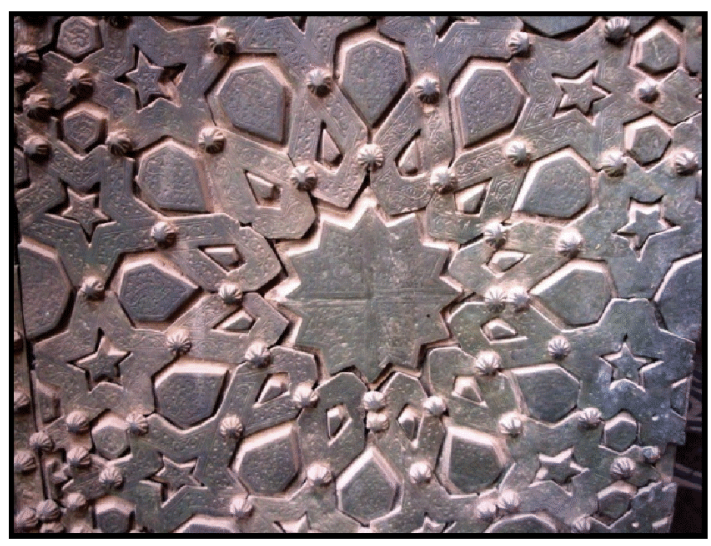

Plate.XI

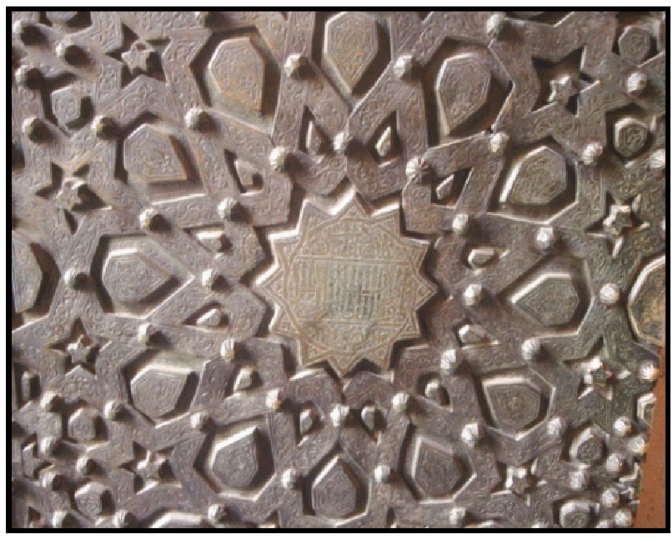

Plate.XII

12- Pointed star pattern-Hanqāh al-Gawrī Photographed by the researcher

12-pointed star- al-Gawrī-madrasah

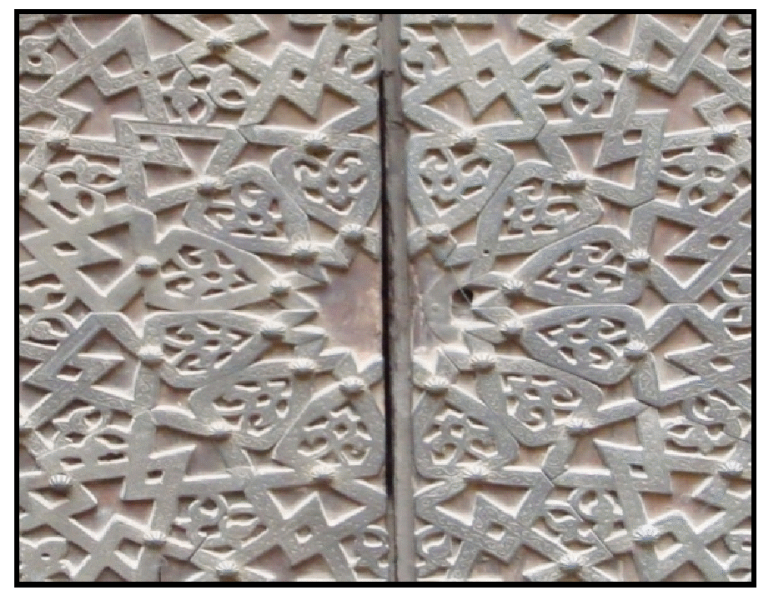

Plate.XIII

12- Pointed star pattern- rear door in the madrasah of al-Gawrī Photographed by the researcher 